Partly supported by the United Nations Development Programme/World Bank/ World Health Organization Special Programme for Research and Training in Tropical Diseases.

Received August 14, 1979

1. Wenk, P., Illgen, B., Seitz, H.M.: Z. Parasitenk. 55, 63 (1978)
2. Wenk, P., Höfler, W.: Z. Tropenmed. 18, 396 (1967)

3. Wong, M.M.: Am. J. Trop. Med. 13, 57, 66 (1964)

4. Wegerhof, P., Wenk, P.: Z. Parasitenk. (in press)

5. Weiss, N., Tanner, M.: Tropenmed. Parasit. 30, 73 (1979)

6. Haque, A., et al.: Parasitology 76, 61 (1978)

7. Illgen, B.: Z. Parasitenk. (in press)

\title{
Karzinom-Immunität bei Mäusen nach Gabe von Mäuse-Embryo-Homogenaten
}

A. Wacker

Abteilung für Therapeutische Biochemie,

Zentrum der Biologischen Chemie der Universität, D-6000 Frankfurt a. M.

Kürzlich berichteten wir über eine aktive Immunisierung mit entkernten Ehrlich-Ascites-Carcinoma-Zellen (Cytoplasten) bei NMRI-Mäusen und teilten mit, daß 20 Tage nach Verabreichung der Cytoplasten die Tiere vollständig gegen diesen $\mathrm{Tu}$ mor resistent waren [1]. In Fortführung dieser Versuche teilen wir nun mit, daß die Tiere auch nach Verabreichung eines Homogenates aus Embryonen von NMRIMäusen gegen Ehrlich-Ascites-CarcinomaZellen resistent werden.

In Anlehnung an eine Arbeit von G. Schöne [2] haben wir Embryonen von NMRI-Mäusen (1 Embryo/ml 0,9\%iger steriler $\mathrm{NaCl}$-Lösung) mit dem UltraThurrax $(20000 \mathrm{U} / \mathrm{min})$ homogenisiert, diese Lösung $3 \mathrm{~min}$ in einem Glas-Homogenisator $(5 \mathrm{ml})$ bei $4{ }^{\circ} \mathrm{C}$ homogenisiert und dann $60 \mathrm{~s}$ mit Ultraschall (Branson Sonifier S 75, Stufe 4, Stromstärke 4,5 A) behandelt. Von dem Homogenat erhielten

Tabelle 1. Schutz von NMRI-Mäusen gegen Ehrlich-Ascites-Carcinoma-Zellen nach Immunisierung mit Embryonen (1 Embryo/ Maus). Tiere mit Tumor waren in beiden Gruppen spätestens nach 32 Tagen tot

\begin{tabular}{lccc}
\hline & $\begin{array}{c}\text { Tag Anzahl } \\
\text { der } \\
\text { Tiere }\end{array}$ & $\begin{array}{l}\text { Kon- } \\
\text { trolle }\end{array}$ \\
\hline $\begin{array}{l}\text { 1. Immunisierung } \\
\text { 2. Immunisierung }\end{array}$ & 0 & 14 & - \\
$\begin{array}{l}\text { Tumorgabe } 5 \cdot 10^{5} \\
\quad \text { Ehrlich-Ascites- } \\
\quad \text { Carcinoma-Zellen }\end{array}$ & 14 & 14 & - \\
$\begin{array}{c}\text { Tiere mit Tumor/ } \\
\text { Gesamtzahl }\end{array}$ & 46 & $3 / 14$ & $10 / 10$ \\
\hline
\end{tabular}

die Mäuse $0,8 \mathrm{ml}$ i.p. Nach 7 Tagen wurde dieser Vorgang wiederholt und nach weiteren 7 Tagen wurden den so behandelten Tieren und Kontrolltieren $5 \cdot 10^{5}$ EhrlichAscites-Carcinoma-Zellen/Maus i.p. verabreicht.
32 Tage nach Tumorgabe waren alle Kontrolltiere gestorben, von den Embryonenimmunisierten dagegen nur 3 von 14 (Tab. 1). Bei der Größe der Embryonen haben wir bei diesen Versuchen keine Auswahl getroffen; der Extrakt wurde von den Mäusen gut vertragen.

Das Ergebnis dieser Untersuchungen zeigt also, da $\beta$ eine Immunität gegen diesen Mäuse-Tumor durch zweimalige Injektion eines Homogenates aus Mäuse-Embryonen erhalten werden kann. Weiteren Untersuchungen bleibt es vorbehalten $\mathrm{zu}$ zeigen, ob diese Immunität humoralen oder zellulären Ursprungs ist.

Wir danken Prof. D. Gericke für die Überlassung der Mäuse-Embryonen und $\mathrm{H}$. Wolf und Frau A. Eichler für geschickte Mithilfe bei den Versuchen.

\section{Eingegangen am 5. Oktober 1979}

1. Wacker, A., Dauch, W., Kaul, S.: Naturwissenschaften 63, 149 (1976)

2. Schöne, G. : Münch. Med. Wschr. 53, 2517 (1906)

\section{Improvement of Tumor Radiotherapy by Recovery Inhibitors}

\author{
J. Kiefer \\ Strahlenzentrum der Universität, D-6300 Giessen \\ F. Dietzel and G. Linhardt \\ Zentrum für Radiologie der Universität, D-6300 Giessen
}

Tumors are thought to contain regions which are poorly supplied with oxygen and nutrients because of disorganized vascularization. Cells in these parts presumably present a major obstacle to radiotherapy since they are still viable but less sensitive to low LET radiation because of the radiobiological oxygen effect and the possible recovery from potentially lethal damage [3]. It was found recently that both recovery from potentially lethal damage and the extent of the oxygen effect can be reduced in yeast cells by the inhibition of protein synthesis [4]. Since it was hoped that this finding might have some bearing on tumor therapy we studied the combined effect of $\mathrm{X}$-rays and the protein-synthesis inhibitor cycloheximide at non-toxic concentrations on the growth of an experimental animal tumor. Our first results, which are reported here, demonstrate that the X-ray action is potentiated and animal survival time increased by this regime.

NMRI mice with solid Ehrlich neck tumors were treated when the tumor volume was $1 \mathrm{ml}$ and the tumor size was followed as a function of time [1]. Fifty animals per group were used. They received either no treatment, $2000 \mathrm{R}$ X-rays locally, cycloheximide (1 mg per animal i.p.) followed immediately by $2000 \mathrm{R} X$-rays or the latter treatment in the reverse order.

Fig. 1a shows tumor growth curves for controls and differently treated animals. It is seen that cycloheximide - which itself had only a small effect-after X-ray exposure inhibits tumor growth significantly more than either X-rays alone or X-rays 